\section{References}

1. Hamilton JB. Male hormone stimulation is prerequisite and an incitant in common baldness. $A m$ Anat 1942;71:451-80.

2 Pochi PE, Strauss JS. Sebaceous gland suppression with ethinyl estradiol and diethylstilbestrol Arh Dermatol 1973;108:210-4.

3 Neumann F, Elger $W$. The effect of a new antiandrogenic steroid 6-chloro-17-hydroxy-1, 2 methylenepregna-4, 6-diene-3, 20-dione acetate (cyprotereone acetate) on the sebaceous glands of mice. F Invest Dermatol 1966;45:561-72.

4 Hammerstein J, Cupceancu B. Behandlung des Hirsutismus mit Cyproteroncetat. Dtsch Med Wocheschr 1969;94:829-39.

5 Fanta D. Hormonal therapy of acne. Clinical and experimental principles. Vienna:Springer-Verlag, 1978.

6 Mugglestone $\mathrm{CJ}$, Rhodes EL. The treatment of acne with an antiandrogen/oestrogen combinaion. Clin Exp Dermatol 1982:7:593-8.

7 Kirby WM, Roberts CE, Burdilk RE. Comparison of two new tetracyclines with tetracycline and demethylchlor tetracycline. In: Finland M, Savage EM, eds. Proceedings of first international conference on antimicrobial agents and chemotheraps. New York: American Society for Microbiology, 1961:286-92.

8 Burke BM, Cunliffe WJ. The assessment of acne vulgaris. The Leeds technique. Br $f$ Dermatol 1984;111:83-92.

9 Strauss JS, Pochi PE. The quantitative gravimetric determination of sebum production. $\mathcal{I}$ Invest Dermatol 1961;36:293-8.

10 Cunliffe WJ, Shuster S. The rate of sebum excretion in man. Br f Dermatl 1969;81:697-704.

11 Williamson P, Kligman AM. A new method for the quantitative investigation of cutaneous bacteria. I Invest Dermatol 1965;45:498-503.

12 Gould DJ, Cunliffe WJ. The long term treatment of acne vulgaris. Clin Exp Dermatol 1978;3
13 Burton JL, Laschet U, Shuster S. Reduction of sebum excretion in man by the antiandrogen cyproterone acetate. Br I Dermatol 1973;89:487-9.

14 Webster GF, McGinley KJ, Leyden JJ. Inhibition of lipase production in Propionibacterium acnes by sub-minimal-inhibitory concentrations of tetracycline and erythromycin. $\mathrm{Br} \mathcal{J}$ acnes by sub-minimal-in
Dermatol $1981 ; 104: 453-7$.

15 Jones DH, Cunliffe WJ, Löffler A. A comparative study of 13-cisretinoic acid and erythromycin in severe acne. In: Cunliffe WJ, Miller AJ, eds. Retinoid therapy. Proceedings of international conference, London, May 1983. London: MTP Press, 1984: 293-301.

16 Goldstein JA, Pochi PE. Failure of benzoyl peroxide to decrease sebaceous gland secretion in acne Dermatologica 1981;162:287-91.

7 Fanta D, Müller MM. Effect of benzoyl peroxide on skin surface lipids. Dermatologica 1979;158:55-9.

18 Cunliffe WJ, Stainton C, Forster RA. Topical benzoyl peroxide increases the sebum excretion rate in patients with acne. $B r$ f Dermatol 1978;109:577-9.

9 Cunliffe WJ, Dodman B, Ead R. Benzoyl peroxide in acne. Practitioner 1978;220:479-82.

20 Holmes RL, Williams M, Cunliffe WJ. Pilo-sebaceous duct obstruction and acne. Br 7 Dermatol 1972;87:327-32.

21 Orme MCE. The clinical pharmacology of oral contraceptive steroids. $\mathrm{Br} f \mathrm{Clin}$ Pharmacol 1982;14:31-42.

22 Pye RJ, Meyrick G, Pye MJ, Burton JL. Effect on oral contraceptives on sebum excretion rate. $B$ r Med f 1977; ;i: 1581-2.

23 Cormane RH, van der Meeren HLM. Cyproterone acetate in the management of severe acne in males. Arch Dermatol Res 1981;271:183-7.

24 Jones DH, King K, Miller AJ, Cunliffe WJ. A dose-response study of 13-cis-retinoic acid in acne vulgaris. Br J Dermatol 1983;108:333-43.

25 Peck GL, Olsen TG, Yoder FW, et al. Prolonged remissions of cystic and conglobate acne with 13-cis-retinoic acid. $N$ Engl f Med 19;9;300:329-33.

Accepted 5 fuly 1985

\title{
Reassessment of inflammation of airways in chronic bronchitis
}

\author{
J BRENDAN M MULLEN, JOANNE L WRIGHT, BARRY R WIGGS, PETER D PARE, \\ JAMES C HOGG
}

\begin{abstract}
The term chronic bronchitis has been criticised because it is associated with hypersecretion of mucus rather than bronchial inflammation. This study was designed to establish the presence or absence of clinical chronic bronchitis and measure pulmonary function in 45 patients about to undergo resection of the lung. The condition in the cartilaginous and small airways and the severity of the emphysema were then measured in the resected specimen. The results from 20 patients who had clinical chronic bronchitis were compared with those in 25 patients who did not. The data show that patients with chronic bronchitis had greater inflammation (a) on mucosal surfaces $(p<0.05)$ of all bronchi larger than $2 \mathrm{~mm}$ luminal diameter and (b) around glands $(p<0.005)$ and gland ducts $(p<0.05)$ in bronchi larger than $4 \mathrm{~mm}$ diameter. A variable degree of inflammation was present in the submucosa of smaller bronchi. The groups had equivalent proportions of mucous glands and Reid's indices in central airways, and no differences were noted in measurements of pulmonary function, condition of small airways, or emphysema.

These data show that the term chronic bronchitis is justified by inflammation of cartilaginous airways and suggest that this abnormality may be the cause of the chronic productive cough.
\end{abstract}

\footnotetext{
University of British Columbia Pulmonary Research Laboratory, St Paul's Hospital, Vancouver, British Columbia, Canada V62 1 Y6

J BRENDAN M MULLEN, MD, FRCP(C), pathologist

JOANNE L WRIGHT, MD, FRCP(C), pathologist

BARRY R WIGGS, BSC, statistician

PETER D PARE, MD, FRCP(C), physician

JAMES C HOGG, MD, professor of pathology

Correspondence and requests for reprints to: Dr Hogg
}

\section{Introduction}

The Ciba Guest symposium of 1959 defined chronic bronchitis as "the condition of subjects with chronic or recurrent excessive mucus secretion in the bronchial tree." As the diagnostic criterion is clinical the relation of hypersecretion of mucus to a condition in the airways in chronic bronchitis has been a source of controversy. Reid described an index of bronchial gland enlargement which she thought correlated with the amount of sputum produced. ${ }^{2}$ Subsequent studies showed that this index was normally distributed without a clear separation between the bronchitic and nonbronchitic groups. ${ }^{3.6}$ Although chronic bronchitis implies inflammation, the absence of documented inflammation of airways in these cases has recently led to objection to the term bronchitis.

The common association of chronic bronchitis and the chronic limitation of airflow led early workers to assume that hypersecretion of mucus resulted in the limitation of airflow. ${ }^{89}$ Recent epidemiological studies, however, have suggested that chronic bronchitis and chronic limitation of airflow should be considered as separate entities rather than as manifestations of a single disease..$^{10-13}$ The site of increased airway resistance in patients with chronic limitation of airflow has been shown to be the small conducting airways, ${ }^{14}$ where the obstruction appears to be due to an inflammatory process. ${ }^{15 \cdot 20}$ This study examines the nature of the condition in the central airways in patients with chronic bronchitis and determines its relation to the condition in the peripheral airways.

\section{Patients and methods}

We studied 45 patients admitted to this hospital for resection of an upper lobe $(n=40)$ or lung $(n=5)$ for, in most cases, bronchial carcinoma. Informed consent was obtained in all cases. A modified questionnaire by the British Medical Research Council was used to assess their exposure to cigarettes, cough, and history of sputum. To examine the differences in condition of airways and function of lungs between patients with chronic bronchitis and those without the patients were divided into two groups: 
those with chronic bronchitis $(\mathbf{n}=20)$, who had had a productive cough occurring on most days for at least three months in the year for at least two successive years, and controls $(n=25)$, who did not have these symptoms.

\section{STUDIES OF PULMONARY FUNCTION}

Pulmonary function tests were performed within the week before surgery with an air conditioned, pressure compensated volume displacement body plethysmograph. Flow was measured with a Fleisch No 3 pneumotachometer coupled to a Sanborn 270 differential pressure transducer (Sanborn Co, Wallham, Massachusetts); volume was measured with a Krogh spirometer coupled to a linear displacement transducer (type $300 \mathrm{NR}$; Shaevitz Engineering, Pennsauken, New Jersey); and transpulmonary pressure was measured with a differential pressure transducer (Validyne $45 \mathrm{MP}, \pm 100 \mathrm{~cm}$ water; Validyne Co, Northridge, California) and an oesophageal balloon catheter. $^{21}$

Functional residual capacity was determined by the Boyle law technique, ${ }^{22}$ and residual volume and total lung capacity were also calculated. Forced expiratory volume in one second and forced vital capacity, as well as maximum flows at $50 \%$ and $25 \%$ of forced vital capacity, were calculated from digitised flow and volume signals during forced expiratory manoeuvres. At least three expiratory efforts were performed, and the forced expiratory manoeuvre with the largest sum of forced expiratory volume in one second and forced vital capacity was selected. Single breath nitrogen washout was performed as described by Buist and Ross, and the slope of phase III was calculated. ${ }^{23}$ Diffusing capacity was measured with the steady state technique in 28 patients according to Bates $e^{2} \mathrm{al}^{4}$ and the single breath technique in 12 patients according to Gaensler and Wright. ${ }^{25}$ Values were expressed as percentages of the predicted value according to the formulas of Morris et al (forced expiratory volume in one second and forced vital capacity) $)^{26}$ and Dosman et al (maximum flows at $50 \%$ and $25 \%$ of forced vital capacity). ${ }^{27}$

\section{MORPHOLOGICAL STUDIES}

Surgically resected specimens were fixed in inflation with $10 \%$ formalin or $3 \%$ buffered glutaraldehyde by intrabronchial infusion at a constant pressure of $25 \mathrm{~cm}$ water for 24 hours. They were then serially sliced in a sagittal plane.

The mid-sagittal slice was used to estimate the degree of emphysema using a modification of the pictorial grading method of Thurlbeck et al. ${ }^{28}$ The emphysema score represents the average value of two observers.

To assess the condition of central airways we obtained samples of five intrapulmonary cartilaginous airways from each specimen. Sections from areas showing bifurcation of airways, presence of tumours, or draining areas of obstructive pneumonitis were excluded. The sections were decalcified in $15 \%$ formic acid for 24 hours, processed for histological examination in the usual manner, then cut at $5 \mu \mathrm{m}$ thickness and stained with haematoxylin and eosin.

All of the measurements in cartilaginous airways were performed using a camera lucida and an Apple II computer assisted digitising board. The luminal diameter of each cartilaginous airway was measured as the maximum distance perpendicular to the long axis of the lumen of the airway. The areas of the lumen-wall, gland, cartilage, smooth muscle, and connective tissue-were measured by tracing each component and expressing it as a percentage of the total tissue area. Reid's index was calculated for each airway whenever possible with the method of Thurlbeck et al. ${ }^{3}$

The cartilaginous airways were also graded with a modification of the pictorial grading method of Cosio et al..$^{15}$ Each airway was divided into quadrants and a separate grade was determined from zero to three for each quadrant, depending on the presence and severity of each of the following: mucosal inflammation, goblet cell metaplasia, squamous cell metaplasia, and mural inflammation affecting glands, gland ducts, nerves, smooth muscle, and interstitium. A single score for each airway was then determined for each variable by summing the quadrant scores and expressing this total as a percentage of the maximum possible score. In addition a score for cartilaginous inflammation of the airways was calculated as the sum of the six components when the maximum was 600 .

To assess the condition of small airways (membranous and respiratory bronchiole) stratified random blocks were taken from both the medial and lateral sagittal slices (three for each slice). The sections were processed for histological examination in the usual manner, cut at $5 \mu \mathrm{m}$ thickness, and stained with haematoxylin and eosin, Masson's trichrome, and periodic acid Schiff. All membranous bronchioles less than $2 \mathrm{~mm}$ internal diameter were evaluated using a modification of the method of Cosio et al. ${ }^{15}$ The respiratory bronchioles were assessed by the method of Wright et al. ${ }^{20}$
ANALYSIS OF DATA

To test the differences in means for age, tests of pulmonary function, measurement of the conditions of cartilaginous and small airways, Reid's indices, and emphysema scores a non-parametric one way layout was performed (Mann-Whitney U test). ${ }^{29}$ Spearman's rank correlation test was used to evaluate the relation of the morphometric variables of the cartilaginous airways to the size of the airways. ${ }^{29}$

\section{Results}

Table I shows that the control group had a mean age of 60 (SD 10) years with a mean history of 959 (683) cigarette years (number of cigarettes smoked a day times number of years of smoking). Of these, seven were exsmokers and the remainder current smokers or those who had stopped smoking within only one year. The group with chronic bronchitis had a mean age of $60(10)$ years and a mean history of $1239(725)$ cigarette years. Of

TABLE I-Mean $(S D)$ data on all patients in study

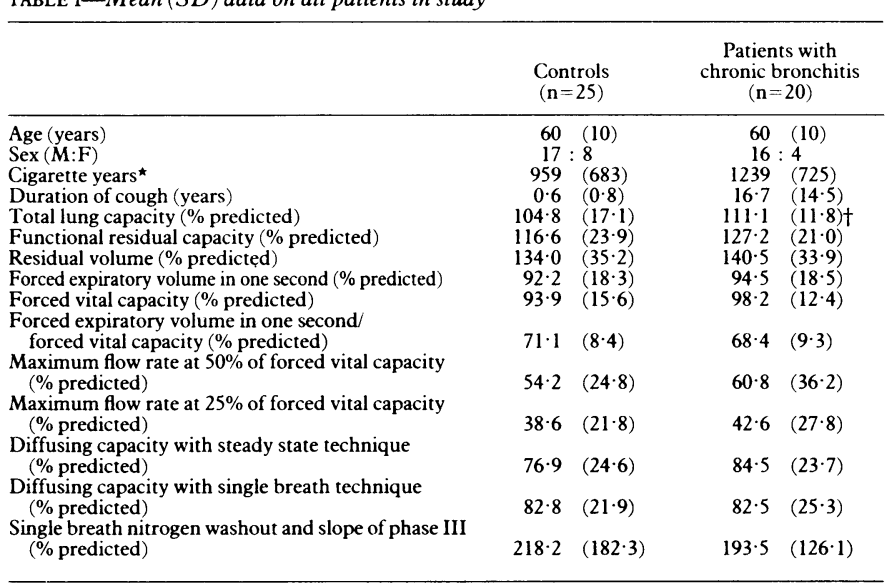

No of cigarettes smoked/day times No of years of smoking.

$\mathrm{tp}<0.05$.

these, three were ex-smokers and the remainder current smokers or those who had stopped smoking within only one year. While the divisions of lung volume (total lung capacity, functional residual capacity, residual volume, and forced vital capacity) tended to be higher in those with chronic bronchitis, only total lung capacity separated the treatment group from the controls $(\mathrm{p}<0.05)$. No differences were noted in measurements of expiratory flow (forced expiratory volume in one second, forced expiratory volume in one second/forced vital capacity, maximum flow at $50 \%$ and $25 \%$ of forced vital capacity), gas transfer (diffusing capacity with steady state technique and single breath technique), or the slope of phase III.

The luminal diameter of the cartilaginous airways correlated positively with the proportions of cartilage $(r=0.40, p<0.001)$, connective tissue $(\mathrm{r}=0.38, \mathrm{p}<0.001)$, and mucous gland $(\mathrm{r}=0.17, \mathrm{p}<0.05)$ and negatively with the proportion of smooth muscle $(r=0.38, p<0.001)$. The data were therefore analysed using the mean values both for each case (mean case data) and for airways (mean airway data) in four different ranges of size $(<2,2-2 \cdot 9$, $3-3 \cdot 9$ and $\geqslant 4 \mathrm{~mm}$ ).

Table II shows the results of the morphometric study of cartilaginous airways. No difference was noted in the size of mcan airways between the patients with chronic bronchitis and the controls. While both the Reid index and the proportion of mucous gland tended to be greater in the chronic bronchitis group, these differences were not significant except for the proportion of mucous gland in those airways $2-2.9 \mathrm{~mm}$ in diameter $(p<0.05)$. Similarly while the proportion of smooth muscle tended to be higher in the chronic bronchitis group, this difference was significant only for the mean case data $(p<0.05)$. Although the controls tended to have a smaller proportion of cartilage to connective tissue than the chronic bronchitis group, the differences were significant only for the proportion of connective tissue in the mean airway data in those airways $2-2.9 \mathrm{~mm}$ $(p<0.01)$ and for the proportions of both cartilage and connective tissue $(\mathrm{p}<0.05)$ in the mean case data.

Table III shows data obtained with the grading system for cartilaginous airways. Compared with controls the chronic bronchitis group had significantly more inflammation, which primarily affected the larger airways. In airways with a luminal diameter greater than $4 \mathrm{~mm}$ the chronic bronchitis 
group had significantly greater mucosal $(p<0 \cdot 05)$, gland $(p<0 \cdot 005)$, gland duct $(p<0.05)$, and total inflammation $(p<0.005)$ than the controls, while in those airways $2-2.9 \mathrm{~mm}$ and $3-3.9 \mathrm{~mm}$ diameter they had significantly greater mucosal $(p<0.05)$ and total inflammation $(p<0.05)$. Interstitial inflammation was also significantly greater $(\mathrm{p}<0.05)$ in those with chronic bronchitis in airways 3-3.9 $\mathrm{mm}$ in diameter. No difference in degree of inflammation was present in cartilaginous airways less than $2 \mathrm{~mm}$ in diameter. Although mucosal, mural (gland, gland duct, interstitium, smooth muscle, and nerve), and total inflammation tended to be higher in the chronic bronchitis group for the mean case data, only mucosal inflammation was significantly different $(\mathrm{p}<0 \cdot 01)$. While a precise differential count of the inflammatory cells was not attempted, the infiltrate was composed predominantly of lymphocytes and plasma cells, with only occasional neutrophils and eosinophils noted. Although goblet cell and squamous cell metaplasia tended to be more noticeable in the chronic bronchitis group, differences in goblet cell metaplasia were only significant in airways larger than $4 \mathrm{~mm}$ $(\mathbf{p}<0.01)$. No difference in deposition of pigment was noted between the two groups.

Relations between inflammation of cartilaginous airways and measurements of mucous gland were significant, although the $r$ values were weak.
TABLE IV-Mean $(S D)$ data on condition of small airways and scores of emphysema

\begin{tabular}{lcc}
\hline & Controls & $\begin{array}{c}\text { Patients with } \\
\text { chronic bronchitis }\end{array}$ \\
\hline $\begin{array}{l}\text { Variables of walls: } \\
\quad \text { Inflammation }\end{array}$ & Membranous bron hioles \\
$\quad$ Fibrosis & $28(12)$ & $35(22)$ \\
Muscle & $29(19)$ & $31(14)$ \\
$\quad$ Pigment & $17(16)$ & $34(20)$ \\
$\quad$ Variables of epithelium: & & $14(11)$ \\
$\quad$ Goblet cell metaplasia & $18(16)$ & $18(17)$ \\
$\quad$ Squamous cell metaplasia & $14(11)$ & $12(10)$ \\
Total scores of condition & $135(40)$ & $143(51)$ \\
& & \\
Variables of walls: & Respiratory bronchioles \\
$\quad$ Inflammation & $18(10)$ & $25(17)$ \\
$\quad$ Fibrosis & $23(17)$ & $25(15)$ \\
$\quad$ Muscle & $13(11)$ & $17(16)$ \\
$\quad$ Pigment & $27(15)$ & $27(16)$ \\
Intraluminal macrophages & $24(11)$ & $22(13)$ \\
Sotal scores of condition & $105(34)$ & $116(35)$ \\
Score of emphysema & $10(11)$ & $15(15)$ \\
& & \\
\hline
\end{tabular}

\begin{tabular}{|c|c|c|c|c|c|c|c|c|c|c|c|c|c|}
\hline & \multicolumn{9}{|c|}{ Mean airway data } & & & \multirow{2}{*}{\multicolumn{2}{|c|}{ Mean case data }} \\
\hline & \multicolumn{11}{|c|}{ Diameter of lumen } & & \\
\hline & \multicolumn{2}{|c|}{$<2 \mathrm{~mm}$} & \multicolumn{4}{|c|}{$2-2 \cdot 9 \mathrm{~mm}$} & \multicolumn{3}{|c|}{$3.3 .9 \mathrm{~mm}$} & \multicolumn{2}{|c|}{$\geqslant 4 \mathrm{~mm}$} & \multirow[b]{2}{*}{ Controls } & \multirow[b]{2}{*}{$\begin{array}{l}\text { Patients with } \\
\text { chronic } \\
\text { bronchitis }\end{array}$} \\
\hline & Controls & $\begin{array}{l}\text { Patients with } \\
\text { chronic } \\
\text { bronchitis }\end{array}$ & Cont & trols & & $\begin{array}{l}\text { nts with } \\
\text { ronic } \\
\text { nchitis }\end{array}$ & & ntrols & $\begin{array}{l}\text { Patients with } \\
\text { chronic } \\
\text { bronchitis }\end{array}$ & Controls & $\begin{array}{l}\text { Patients with } \\
\text { chronic } \\
\text { bronchitis }\end{array}$ & & \\
\hline $\begin{array}{l}\text { Gland (\%) } \\
\text { Smooth muscle (\%) } \\
\text { Cartilage (\%) } \\
\text { Connective tissue (\%) } \\
\text { Reid's index }\end{array}$ & $\begin{array}{cc}3.5 & (1 \cdot 8) \\
3.1 & (2.5) \\
10.7 & (6 \cdot 4) \\
82.7 & (6 \cdot 7) \\
0.41 & (0 \cdot 19)\end{array}$ & $\begin{array}{cc}3 \cdot 2 & (2 \cdot 6) \\
3.1 & (1 \cdot 6) \\
14 \cdot 5 & (8 \cdot 5) \\
79 \cdot 2 & (10.1) \\
0.32 & (0 \cdot 10)\end{array}$ & $\begin{array}{c}3 \cdot 3 \\
2 \cdot 1 \\
16 \cdot 3 \\
78 \cdot 3 \\
0.38\end{array}$ & $\begin{array}{l}(2.6) \\
(1.1) \\
(8.9) \\
(8 \cdot 9) \\
(0 \cdot 14)\end{array}$ & $\begin{array}{c}4 \cdot 6 \\
2 \cdot 3 \\
21 \cdot 3 \\
71 \cdot 8 \\
0 \cdot 41\end{array}$ & $\begin{array}{l}(3.0)^{\star} \\
(1.2) \\
(9.9) \\
(9.3)^{\star \star} \\
(0.11)\end{array}$ & $\begin{array}{c}4 \cdot 5 \\
1 \cdot 8 \\
20 \cdot 1 \\
.73 .6 \\
0.35\end{array}$ & $\begin{array}{l}(2 \cdot 9) \\
(0 \cdot 9) \\
(8 \cdot 5) \\
(8 \cdot 3) \\
(0 \cdot 10)\end{array}$ & $\begin{array}{rr}5.2 & (3.5) \\
2.2 & (1.3) \\
21.1 & (7.7) \\
73.6 & (8.3) \\
0.40 & (0.09)\end{array}$ & $\begin{aligned} 4 \cdot 0 & (2 \cdot 7) \\
1.3 & (0.6) \\
24 \cdot 0 & (10.0) \\
70.7 & (9.6) \\
0.38 & (0 \cdot 11)\end{aligned}$ & $\begin{aligned} 4 \cdot 8 & (3 \cdot 0) \\
1.7 & (0 \cdot 6) \\
24 \cdot 7 & (9 \cdot 9) \\
68.8 & (9 \cdot 9) \\
0.43 & (0 \cdot 15)\end{aligned}$ & $\begin{array}{cc}3 \cdot 8 & (2 \cdot 6) \\
2 \cdot 0 & (1.5) \\
18.1 & (9 \cdot 8) \\
76.1 & (9 \cdot 5) \\
0.37 & (0 \cdot 12)\end{array}$ & $\begin{array}{cc}4 \cdot 4 & (3 \cdot 1) \\
2 \cdot 4 & (1 \cdot 3) \star \\
20 \cdot 1 & (9 \cdot 7)^{\star} \\
73 \cdot 2 & (10 \cdot 1)^{\star} \\
0 \cdot 40 & (0 \cdot 12)\end{array}$ \\
\hline
\end{tabular}

TABLE III-Mean (SD) data on condition of cartilaginous airways

\begin{tabular}{|c|c|c|c|c|c|c|c|c|c|c|}
\hline & \multicolumn{8}{|c|}{ Mean airway data } & \multirow{2}{*}{\multicolumn{2}{|c|}{ Mean case data }} \\
\hline & \multicolumn{8}{|c|}{ Diameter of lumen } & & \\
\hline & \multicolumn{2}{|c|}{$<2 \mathrm{~mm}$} & \multicolumn{2}{|c|}{$2-2.9 \mathrm{~mm}$} & \multicolumn{2}{|c|}{$3-3.9 \mathrm{~mm}$} & \multicolumn{2}{|c|}{$\geqslant 4 \mathrm{~mm}$} & \multirow[b]{2}{*}{ Controls } & \multirow[b]{2}{*}{$\begin{array}{c}\text { Patients witl } \\
\text { chronic } \\
\text { bronchitis }\end{array}$} \\
\hline & Controls & $\begin{array}{l}\text { Patients with } \\
\text { chronic } \\
\text { bronchitis }\end{array}$ & Controls & $\begin{array}{l}\text { Patients with } \\
\text { chronic } \\
\text { bronchitis }\end{array}$ & Controls & $\begin{array}{l}\text { Patients with } \\
\text { chronic } \\
\text { bronchitis }\end{array}$ & Controls & $\begin{array}{l}\text { Patients with } \\
\text { chronic } \\
\text { bronchitis }\end{array}$ & & \\
\hline $\begin{array}{l}\text { Inflammation of: } \\
\text { Mucosa } \\
\text { Glands } \\
\text { Gland ducts } \\
\text { Interstitium } \\
\text { Smooth muscle } \\
\text { Nerves }\end{array}$ & $\begin{aligned} 40 & (31) \\
30 & (16) \\
28 & (31) \\
23 & (21) \\
2 & (5) \\
5 & (8)\end{aligned}$ & $\begin{aligned} 54(30) \\
23(16) \\
12(19) \\
17(24) \\
2(7) \\
7(11)\end{aligned}$ & $\begin{aligned} & 46(30) \\
& 28(16) \\
& 14(22) \\
& 18(23) \\
& 2(8) \\
& 3(6)\end{aligned}$ & $\begin{aligned} 62 & (30)^{\star} \\
30 & (14) \\
22 & (24) \\
23 & (18) \\
2 & (7) \\
6 & (12)\end{aligned}$ & $\begin{aligned} & 41(40) \\
& 28(12) \\
& 24(20) \\
& 16(19) \\
& 1(2) \\
&(7)\end{aligned}$ & $\begin{aligned} & 68(26)^{\star} \\
& 33(17) \\
& 23(21) \\
& 28(23)^{\star} \\
& 6(14) \\
& 5(10)\end{aligned}$ & $\begin{aligned} 32 & (37) \\
29 & (12) \\
19 & (18) \\
14 & (17) \\
1 & (5) \\
2 & (5)\end{aligned}$ & $\begin{aligned} 64 & (41)^{\star} \\
42 & (10)^{\star \star \star \star} \\
35 & (24)^{\star} \\
21 & (22) \\
4 & (9) \\
4 & (8)\end{aligned}$ & $\begin{aligned} 40 & (26) \\
29 & (9) \\
20 & (15) \\
17 & (14) \\
1 & (4) \\
3 & (3)\end{aligned}$ & $\begin{aligned} 61 & (21)^{\star \star \star} \\
31 & (12) \\
22 & (16) \\
22 & (16) \\
3 & (6) \\
6 & (7)\end{aligned}$ \\
\hline Total inflammation & $128(77)$ & $113(76)$ & $111(77)$ & $145(67)^{\star}$ & $111(71)$ & $162(81)^{\star}$ & $96(67)$ & $169(88)^{\star \star \star}$ & $111(55)$ & $144(61)$ \\
\hline $\begin{array}{l}\text { Epithelial variables: } \\
\text { Goblet cell metaplasia } \\
\text { Squamous cell }\end{array}$ & $47(34)$ & $54(39)$ & $51(40)$ & $49(31)$ & $37(39)$ & $53(33)$ & $7(15)$ & $39(38)^{\star \star}$ & $36(28)$ & $50(24)$ \\
\hline $\begin{array}{l}\text { metaplasia } \\
\text { Deposition of pigment }\end{array}$ & $\begin{aligned} 1 & (1) \\
17 & (11)\end{aligned}$ & $\begin{aligned} 1 & (4) \\
15 & (12)\end{aligned}$ & $\begin{array}{ll}1 & (1) \\
21 & (13)\end{array}$ & $\begin{aligned} 4 & (9) \\
20 & (14)\end{aligned}$ & $\begin{aligned} 1 & (2) \\
18 & (12)\end{aligned}$ & $\begin{aligned} 8(20) \\
14(11)\end{aligned}$ & $\begin{array}{l}11(28) \\
11(13)\end{array}$ & $\begin{aligned} & 5(21) \\
& 12(13)\end{aligned}$ & $\begin{aligned} & 3(8) \\
& 17(8)\end{aligned}$ & $\begin{array}{c}4(9) \\
16(10)\end{array}$ \\
\hline
\end{tabular}

The proportion of mucous gland was found to correlate with gland $(r=0 \cdot 15$, $\mathrm{p}<0.05)$, gland duct $(\mathrm{r}=0.28, \mathrm{p}<0.001)$, and total inflammation of airways $(\mathrm{r}=0.17, \mathrm{p}<0.01)$, while Reid's index was found to correlate only with inflammation of the gland duct $(r=0 \cdot 22, p<0 \cdot 01)$.

Table IV shows the data obtained with the grading system for membranous bronchioles, respiratory bronchioles, and the estimates of emphysema. This shows that means of the groups were not significantly different, although the chronic bronchitis group showed a trend towards greater inflammation, smooth muscle hypertrophy, and scores of total condition.

\section{Discussion}

The results of this study show that chronic bronchitis is associated with inflammation of cartilaginous airways and that the severity of this reaction correlates roughly with the size of mucous glands. The reaction consisted primarily in the infiltration of mononuclear inflammatory cells, although polymorphonuclear cells were occasionally present. This response was seen most clearly on the mucosal surfaces of all bronchi greater than $2 \mathrm{~mm}$ in diameter and around the glands and gland ducts in airways greater than $4 \mathrm{~mm}$ in diameter and was variably present in the submucosa of the smaller bronchi (table III). The data show that walls of cartilaginous airways are composed of 3-5\% glands, $1-3 \%$ smooth muscle, $10-25 \%$ cartilage, and $68-72 \%$ connective tissue (table II). These values are similar to those in previous published reports. ${ }^{30-34}$ Table II also shows that there is little difference in the structure of cartilaginous airways between patients with bronchitis and those without except for a slight increase in the proportions of smooth muscle and connective tissue. The estimates of both the severity of the 
inflammatory reaction and the proportion of mucus gland were normally distributed, with the total score for inflammation ranging from 0 to 375 and Reid's index from $0 \cdot 114$ to 0.736 . A $\chi^{2}$ analysis showed that a significant difference $(\mathrm{p}<0.005)$ existed between patients with chronic bronchitis and controls with respect to the score for inflammation of the central airways but not with respect to the Reid index $(p>0.05)$. The mucosal inflammation was also associated with goblet cell metaplasia in the larger airways. These data suggest that chronic cough and production of sputum are associated with an inflammatory reaction in the cartilaginous airways. Based on the classic studies of Florey et al on the inflammatory reaction in mucous membranes, ${ }^{35}$ we can reasonably conclude that the mucosal inflammation in cartilaginous airways is responsible for the production of excess mucus that accounts for clinical chronic bronchitis.

Several problems are inherent in a study of this type. The assessment of cough, production of sputum, and consumption of cigarettes by interview is probably not accurate. We attempted to minimise this problem by using interviewers who had no knowledge of the data on the histological nature or function of airways to collect the information preoperatively by questionnaire. Only patients requiring upper lobectomy or pneumonectomy were selected to minimise differences between lobes. The size, type, and location of the tumours did not differ between the groups, so the differences in amount of inflammation present could not be attributed to the tumours. Previous morphometric studies of cartilaginous airways have generally been limited to segmental or larger airways, with the results presented as mean values. ${ }^{31.34}{ }^{36}$ Recent studies, however, have reported that structural proportions of airways vary with the diameter. ${ }^{31} 37$ To control for the relation of the proportion and diameter of airways that was present in our data we carried out the analysis in both the conventional manner (mean case data) and after division into four groups on the basis of luminal diameter (mean airway data). A recent comparison of the condition of small airways in upper and lower lobes by Wright $e t a l^{38}$ with the same grading system showed that, with the exception of a slight increase in respiratory bronchiolitis in lower lobes, no differences existed between upper and lower lobes. Grading of emphysema was restricted to an upper lobe in 40 of the 45 cases. By modifying the pictorial grading method of Thurlbeck et $a l^{8}$ and restricting comparisons to lobes obtained from similar sites we minimised the variation based on sample sites inherent in estimating emphysema.

The relation of hypersecretion of mucus to alterations in the apparatus secreting mucus is well established. Although the actual method of measuring the secretory apparatus has varied (Reid's index,${ }^{2}$ mucous gland proportion, ${ }^{30}$ gland thickness, ${ }^{39}$ gland area, ${ }^{40}$ and acinar size $^{2}$ ), most authors agree that mucous glands become enlarged in chronic bronchitis. Considerable overlap exists, however, in the values obtained from patients with chronic bronchitis and from those without. Reid's index has been reported to have a unimodel distribution of frequency, ${ }^{3.6}$ and indeed this pattern was apparent in this study for both the mean airway data and the mean case data. A complicating factor in assessing the size of mucous glands is the effect of cigarette smoking. While the relation of smoking to size of the bronchial gland is less well established, cigarette smokers tend to have larger mucous glands. ${ }^{6173941}$ Our inability to detect a difference in the proportion of mucous glands between groups except for those airways $2-2.9 \mathrm{~mm}$ in diameter could mean that cigarette smoking had affected the size of mucous gland maximally in both groups.

The difference in inflammation of cartilaginous airways observed between the two groups suggests that inflammation rather than hypertrophy of mucous gland provides the better morphological indication of chronic bronchitis. We found that the score for inflammation of cartilaginous airways and Reid's index were fairly normally distributed. Unlike Reid's index, however, inflammation of cartilaginous airways separated those patients with chronic bronchitis from those without. This difference was highly significant for the mean airway data $(\mathrm{p}<0.001)$ and approached significance for the mean case data $(p<0.06)$. This differs from several previous reports, which found that inflammation was not a significant feature of chronic bronchitis. Reid, in two studies combining resectional, biopsy, and necropsy material, ${ }^{2 x}$ and Field $\underline{\underline{\sigma}}$ et al, in a necropsy survey, ${ }^{42}$ commented that in most cases inflammatory infiltration was slight. Salvato, ${ }^{43}$ in an examination $\stackrel{\otimes}{\stackrel{2}{ }}$ limited to biopsy material, found that infiltrates of chronic inflam- $c$ matory cells in the subepithelial connective tissue were not different $\widehat{\widehat{O}}$ between controls and patients with chronic bronchitis and asthma. $\bar{\Xi}$ In contrast, using a grading system similar to that in this study, ग Martin $e t \mathrm{al}^{+4}$ found a significant relation between inflammation and $\mathbb{\infty}$ the presence of cough but not production of sputum. Their failure $\Omega^{\prime}$ to show a relation with production of sputum may be accounted for in part by their case selection, as 51 of their 70 patients had $\underset{\vec{S}}{\vec{\rho}}$ tuberculosis at the time of the study.

Studies of the amount of smooth muscle in bronchial walls in cases of chronic bronchitis are contradictory. Dunnill et $a l^{31} \frac{\bar{\sigma}}{\overline{\frac{9}{}}}$. examined 19 patients with chronic bronchitis and found no $\vec{\Phi}$ difference in proportion of smooth muscle when compared with $11 \propto$ controls. In contrast, Hossain and Heard reported that the amount is of muscle in major bronchi in chronic bronchitis may be increased $\overrightarrow{0}$ more than twofold as a result of hyperplasia. ${ }^{45}$ Takizawa and Thurlbeck compared seven patients with typical chronic bronchitis $\vec{\rho}$ and four patients with chronic bronchitis and attacks of wheezing $\partial$ and found that three of the four subjects in the group with additional 3 . attacks of wheezing had more muscle. ${ }^{32}$ They suggested that the previously reported discrepancies in content of smooth muscle may have been due to the inclusion of different proportions of patients or $^{\circ}$ with chronic bronchitis and asthma. We were able to detect a $\varnothing$ significant increase only in the proportion of smooth muscle in $\vec{N}$ bronchial walls with the mean case data. As none of our subjects $\mathrm{W}_{\mathrm{G}}$ were known to suffer from asthma we were unable to attribute the increased proportion of smooth muscle in cases of chronic bronchitis to differences in the proportion of patients with asthma.

Our evaluation of the proportion of cartilage in bronchial walls was in keeping with the findings of others that the amount of $\frac{\Phi}{3}$ cartilage does not decrease in chronic bronchitis. ${ }^{31324647}$ This contrasts with the findings of Tandon and Campbell, ${ }^{48}$ who used a $\stackrel{\mathbb{}}{-}$ different method of assessment and showed a deficiency in the $\vec{\varphi}$ average extent of circumferentially arranged cartilage along bronchi ơ in chronic bronchitis. Thurlbeck et $a l,{ }^{49}$ however, in a study similar $\square$ to that of Tandon and Campbell found that atrophy of cartilage did not correlate with chronic bronchitis as assessed either clinically or morphologically.

Several studies have shown the importance of the relation of $\frac{0}{\mathbb{Q}}$ inflammation and fibrosis of the membranous and respiratory $\stackrel{\varrho}{\Rightarrow}$ bronchioles and goblet cell metaplasia of the membranous bronchi- $\overrightarrow{\overrightarrow{0}}$ oles to limitation of airflow. ${ }^{15-2038}$ In this study there was no $\frac{3}{5}$ difference in the degree of abnormalities of small airways or scores of emphysema between those patients who had chronic bronchitis and those who did not. These data further support the hypothesis that chronic bronchitis, limitation of chronic airflow, emphysema, and disease of small airways are separate although interrelated $\frac{\sigma}{3}$ entities. ${ }^{10-13}$

In our population inflammation of cartilaginous airways best $\bar{\delta}$ separated those patients with chronic bronchitis from controls. The differences in inflammation were related directly to the diameter of $\frac{\mathrm{O}}{2}$ airways and were more pronounced in larger airways. While the $N$ precise pathophysiological mechanisms associated with the relation between inflammation-hypertrophy of mucous glands-and hypersecretion of mucus are not known, the underlying factor appears to be cigarette smoking. As both groups had similar 0 proportions of mucous gland and exposure to cigarettes, the $\underset{\omega}{ }$ enhanced relation of inflammation to hypersecretion of mucus in patients with chronic bronchitis suggests a differential response to cigarette smoke. Whether this difference is due to the pattern of inhaling smoke, ${ }^{50.52}$ the type of cigarette smoked, ${ }^{50}$ or differences in $\stackrel{?}{?}$ the nature of the lung defence mechanism, ${ }^{53.58}$ including the inflammatory response, ${ }^{59}$ remains uncertain.

We thank Catherine Coppin and Sally Osborne for technical work and Lee Kowk and Sheree Corbett for secretarial help. The study was supported by $\delta$ the Medical Research Council of Canada, the British Columbia Lung Association, and the Canadian Tobacco Manufacturers Council. 


\section{References}

1 Ciba Guest Symposium. Terminology, definitions and classifications of chronic pulmonary emphysema and related conditions. Thorax 1959:14:286-99.

2 Reid L. Measurement of the bronchial mucous gland layer: a diagnostic yardstick in chronic bronchitis. Thorax 1960;15:132-41.

3 Thurlbeck WM, Angus GE. A distribution curve for chronic bronchitis. Thorax 1964;19:436-42.

4 Hayes JA. Distribution of bronchial gland measurements in a Jamaican population. Thorax 1969;24:619-22.

McKenzie HI, Glick M, Outhred KG. Chronic bronchitis in coal miners: ante-mortem/postmortem comparisons. Thorax 1969;24:527-35.

6 Scott KWM. An autopsy study of bronchial mucous gland hypertrophy in Glasgow. Am Rev Respir Dis 1973;107:239-45.

7 Fletcher CM, Pride NB. Definitions of emphysema, chronic bronchitis, asthma, and airflow obstruction: 25 years on from the Ciba symposium. Thorax 1984;39:81-5.

8 Reid L. Pathology of chronic bronchitis. Lancet $1954 ; \mathrm{i}: 275-8$.

9 MacLean KH. The histology of generalized pulmonary emphysema. I. The genesis of the early centrolobular lesion: focal emphysema. Australasian Annals of Medicine 1957;6:124-40.

10 Sharp JT, Paul O, McKean H, Best WR. A longitudinal study of bronchitic symptoms and spirometry in a middle-aged, male, industrial population. Am Rev Respir Dis 1973;108: 1066-77.

11 Bates DV. The fate of the chronic bronchitic. Am Rev Respir Dis 1973;108:1043-65.

12 Fletcher C, Peto R. The natural history of chronic airflow obstruction. Br Med f 1977;i: 1645-8.

13 Peto R, Speizer FE, Cochrane AL, et al. The relevance in adults of airflow obstruction, but not of mucus hypersecretion, to mortality from chronic lung disease. Am Rev Respir Dis 1983;128 491-500.

14 Hogg JC, Macklem PT, Thurlbeck W. Site and nature of airway obstruction in chronic obstructive lung disease. $N$ Engl I Med 1968;278:1355-60

15 Cosio $\mathrm{M}$, Ghezzo H, Hogg JC, et al. The relations between structural changes in small airways and pulmonary-function tests. $N$ Engl 7 Med 1978;298:1277-81.

16 Berend N, Woolcock AJ, Marlin GE. Correlation between the function and structure of the lung in smokers. Am Rev Respir Dis 1979;119:695-705.

17 Cosio MG, Hale KA, Niewoehner DE. Morphologic and morphometric effects of prolonged cigarette smoking on the small airways. Am Rev Respir Dis 1980;122:265-71.

18 Petty TL, Silvers W, Stanford RE, Baird D, Mitchel RS. Small airways pathology is related to increased closing capacity and abnormal slope of phase III in excised human lungs. Am Rev Respir Dis 1980;121:449-56.

19 Berend N, Wright JL, Thurlbeck WM, Marlin GE, Woolcock AJ. Small airways disease: reproducibility of measurements and correlation with lung function. Chest 1981;79:263-8.

20 Wright JL, Lawson LM, Pare PD, Kennedy S, Wiggs B, Hogg JC. The detection of small airways disease. Am Rev Respir Dis 1984;129:989-94.

21 Pare PD, Harvey K, Mildenberger M, Brooks LA. The effects of balloon volume and position on the pressure volume curve of the lung. Clin Invest Med 1983;6:143-6.

22 Dubois AB, Botelho SY, Bedel GW, Marshall R, Comroe JH. A rapid plethysmographic method for measuring thoracic gas volume: a comparison with a nitrogen washout method for measuring functional residual capacity in normal subjects. $\mathcal{F}$ Clin Invest 1956;35:322-6.

23 Buist AS, Ross BB. Quantitative analysis of the alveolar plateau in the diagnosis of early airway obstruction. Am Rev Respir Dis 1973;108:1078-87.

24 Bates DV, Woolf CR, Paul GI. Chronic bronchitis: a report on the first two stages of the coordinated study of chronic bronchitis in the Department of Veterans Affairs, Canada. Medical Services fournal, Canada 1962;18:211-303.

25 Gaensler EA, Wright GW. Evaluation of respiratory impairment. Arch Environ Health 1966;12: 146-89.

26 Morris JF, Koski A, Johnson LC. Spirometric standards for healthy nonsmoking adults. Am Rev Respir Dis 1971;103:57-67.

27 Dosman J, Bode F, Urbanetti J, Martin R, Macklem PT. The use of a helium-oxygen mixture during expiratory flow to demonstrate obstruction in small airways in smokers. $f$ Clin Invest 1975;55:1090-9.

28 Thurlbeck WM, Dunnill MS, Hartung W, Heard BE, Heppleston AG, Ryder RC. A comparison of three methods of measuring emphysema. Hum Pathol 1972;1:215-26.

29 Hollander M, Wolfe DA. Nonparametric statistical methods. New York: John Wiley and Sons, 1973:71-82.

29a Hollander M, Wolfe DA. Nonparametric statistical methods. New York: John Wiley and Sons, 1973:185-99.
30 Hale FC, Olsen CR, Mickey MR. The measurement of bronchial wall components. Am Rev Respir Dis 1968;98:978-87.

31 Dunnill MS, Massarella GR, Anderson JA. A comparison of the quantitative anatomy of the bronchi in normal subjects, in status asthmaticus, in chronic bronchitis, and in emphysema. Thorax 1969;24:176-9.

32 Takizawa T, Thurlbeck WM. Muscle and mucous gland size in the major bronchi of patients with hronic bronchitis, asthma and asthmatic bronchitis. Am Rev Respir Dis 1971;104:331-6.

33 Niewoehner DE, Kleinerman J, Knoke JD. Regional chronic bronchitis. Am Rev Respir Dis 1972;105:586-93

34 Oberholzer M, Dalquen P, Rohr HP. Stereology, a complement to respiration research. Bronchus morphometry: methodology and baseline data. Microsc Acta 1977;79:205-23.

35 Florey HW. The secretion of mucus and inflammation of mucous membranes. In: Florey HW, ed General pathology. 3rd ed. London: Lloyd-Luke Ltd, 1962:167-96.

36 Takizawa T, Thurlbeck WM. A comparative study of four methods of assessing the morphologic Changes in chronic bronchitis. Am Rev Respir Dis 1971:103:774-83.

37 Carlile A, Edwards C. Structural variation in the named bronchi of the left lung. A morphometric study. Br $\mathcal{F}$ Dis Chest 1983;77:344-8.

38 Wright JL, Wiggs BJ, Hogg JC. Airway disease in upper and lower lobes in lungs of patients with and without emphysema. Thorax 1984;39:282-5.

39 Thurlbeck WM, Angus GE, Pare JAP. Mucous gland hypertrophy in chronic bronchitis, and its occurrence in smokers. Br 7 Dis Chest 1963;57:73-8.

40 Restrepo G, Heard BE. The size of the bronchial glands in chronic bronchitis. Fournal of Pathology and Bacteriology 1963;85:305-10.

41 Ryder RC, Dunnill MS, Anderson JA. A quantitative study of the bronchial mucous gland volume, emphysema and smoking in a necropsy population. F Pathol 1971;104:59-71.

42 Field WEH, Davey EN, Reid L, Roe FJC. Bronchial mucus gland hypertrophy: its relation to symptoms and environment. Br $\mathcal{F}$ Dis Chest 1966;60:66-80.

43 Salvato G. Some histological changes in chronic bronchitis and asthma. Thorax 1968;23:168-72.

44 Martin C, Katsura S, Cochran TH. The relationship of chronic bronchitis to the diffuse obstructive pulmonary syndrome. Am Rev Respir Dis 1970;102:362-9.

45 Hossain S, Heard BE. Hyperplasia of bronchial muscle in chronic bronchitis. I Pathol 1970;101:171-84.

46 Restrepo GL, Heard BE. Air trapping in chronic bronchitis and emphysema: measurement of the bronchial cartilage. Am Rev Respir Dis 1964;90:395-400.

47 Greenberg SD, Boushy SF, Jenkins DE. Chronic bronchitis and emphysema: correlation of pathologic findings. Am Rev Respir Dis 1967;96:918-28.

48 Tandon MK, Campbell AH. Bronchial cartilage in chronic bronchitis. Thorax 1969;24:607-12.

49 Thurlbeck WM, Pun R, Toth J, Frazer RG. Bronchial cartilage in chronic obstructive lung disease. Am Rev Respir Dis 1974;109:73-80.

50 Tobin MJ, Jenouri G, Sackner MA. Subjective and objective measurement of cigarette smoke inhalation. Chest 1982;82:696-700

51 Valberg PA, Brain JD, Sneddon SL, LeMott SR. Breathing patterns influence aerosol deposition sites in excised dog lungs. F Appl Physiol 1982;53:824-37.

52 Higenbottom T, Feyeraband C, Clark TJH. Cigarette smoke inhalation and the acute airway response. Thorax 1980;35:246-54.

53 Falk HL, Tremer HM, Kotin P. Effect of cigarette smoke and its constituents on ciliated mucussecreting epithelium. Fournal of the National Cancer Institute 1959;23:999-1012.

54 Ailsby RL, Ghadially FN. A typical cilia in human bronchial mucosa. 7 Pathol 1973;109:75-8

55 McDowell EM, Barrett LA, Harris CC, Trump BF. Abnormal cilia in human bronchia epithelium. Arch Pathol Lab Med 1976;100:429-326.

56 Rossman CM, Lee RMKW, Forrest JB, Newhouse MT. Nasal ciliary ultrastructure and function in patients with primary ciliary dyskinesia compared with that in normal subjects and in subjects with various respiratory diseases. Am Rev Respir Dis 1984;129:161-7.

57 Camner P, Philipson K. Tracheobronchial clearance in smoking — discordant twins. Arch Environ Health 1972;25:60-3.

58 Sanchis J, Dolovich $M$, Rossman C, Newhouse $M$. Lung clearance in patients with airways obstruction. Bulletin de Physio-Pathologie Respiratoire (Nancy) 1973;9:325-35.

$59 \mathrm{Katz}$ DH, Mead R. Control of antibody synthesis. In: Middleton E, Reed C, Ellis EF, eds. Allergy: principles and practice. 2 nd ed. St Louis: C V Mosby, 1983:31-42.

(Accepted 10 fuly 1985)

\section{SHORT REPORTS}

\section{Toxocariasis and eosinophilic meningitis}

Toxocariasis is usually manifested as visceral larva migrans in young children with pica. ${ }^{1}$ Lesions in the eye are more common in older children and adults, ${ }^{2}$ and rarely other parts of the central nervous system may be affected. ${ }^{2} \mathrm{~A}$ benign, self limiting meningitis has not been described and we therefore report such a case.

\section{Case history}

A previously healthy 11 year old girl was referred by her general practitioner with a 10 day history of worsening neck stiffness and back pain She had initially presented with severe bilateral frontal headache and dizziness but these symptoms had resolved within $\mathbf{4 8}$ hours after beginning treatment with paracetamol.

On examination the child looked alert and well and was not feverish. There was pronounced meningism and she complained of severe pain at the level of T12-L1, accentuated by movement. Kernig's sign was positive and both optic discs were blurred. There was generalised hyperreflexia. The rest of the physical examination, routine blood tests, and radiography showed nothing unusual. An urgent CT scan showed no abnormality. Lumbar punc- ture the day after admission yielded 150 white cells, reported initially as being predominantly lymphocytes with normal protein and glucose. In view of the atypical history Romanovsky staining was performed on a cytospin of cerebrospinal fluid. This showed that $30 \%$ of the cells were eosinophils and that the remainder were lymphocytes. Culture and serology for common viral and bacterial infection were unhelpful. Two days after admission an eosinophilia of $1.3 \times 10^{9} / 1$ was noted, which persisted to follow up at six weeks.

The patient recovered spontaneously over the next three days and was sent home. Results of serological screening for toxocaral infection suggested active infection (see table), both acute and convalescent serum samples having appreciable titres. Anti-A agglutinin titres were also raised but fell during convalescence, were IgG only, and the patient had never had a blood transfusion, all points suggestive of acute toxocaral infection. She denied pica but both neighbours had recently acquired puppies, ensuring a plentiful supply of toxocara ova.

She was treated with diethylcarbamazine $8 \mathrm{mg} / \mathrm{kg}$ for 10 days and tolerated the treatment well. She continued to be asymptomatic nine months after presentation.

\section{Comment}

This case was unusual in its presentation and is instructive in the method of diagnosis. Pronounced eosinophilia in the cerebrospinal fluid is rare in Britain but there are many recognised causes. ${ }^{3}$ Other 